\title{
Length-weight relationship and diet of the catfish Cambeva guareiensis (Siluriformes; Trichomycteridae)
}

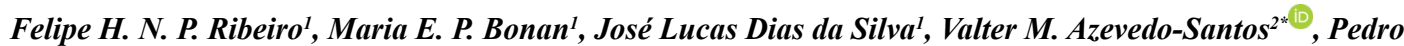 \\ S. Manoel $^{\circledR}$, Eduardo M. Brambilla ${ }^{2}$, Carolina V. Silva ${ }^{1}$ \\ ${ }^{1}$ Faculdade Eduvale de Avaré, Avaré, SP, Brasil \\ ${ }^{2}$ Universidade Estadual Paulista “Júlio de Mesquita Filho”, Botucatu, SP, Brasil \\ *Corresponding author: valter.ecologia@gmail.com
}

RIBEIRO, F.H.N.P., BONAN, M.E.P., SILVA, J.L.D., AZEVEDO-SANTOS, V.M., MANOEL, P.S., BRAMBILLA, E.M., SILVA, C.V. Length-weight relationship and diet of the catfish Cambeva guareiensis (Siluriformes; Trichomycteridae). Biota Neotropica 21(4): e20211236. https://doi.org/10.1590/1676-0611-BN-2021-1236

\begin{abstract}
The length-weight relationship (LWR) and diet of a small trichomycterid catfish, Cambeva guareiensis, was studied based on 58 specimens captured in Corrente stream, Guareí River basin, São Paulo, Brazil. LWR analyses showed values of $a$ ranged from 0.0097 to 0.0149 and $b$ from 2.858 to 3.250 . The analysis of the diet showed that high amounts of aquatic insects $(93.75 \%$ of total items) were consumed by the species. In addition, we found no statistically significant differences when comparing the diet between the dry and rainy periods. Our study contributes to the knowledge on populational biology and feeding ecology of trichomycterid fishes in Brazilian streams.

Keywords: Chironomidae; Functional trait; Populational biology; Stomach content; Stream fish; Upper Paraná basin.

\section{Relação peso-comprimento e dieta do bagre Cambeva guareiensis (Siluriformes; Trichomycteridae)}

\footnotetext{
Resumo: A relação peso-comprimento (RPC) e dieta de um pequeno bagre trichomycterídeo, Cambeva guareiensis, foi estudada com base em 58 espécimes capturados no riacho Corrente, bacia do rio Guareí, São Paulo, Brasil. As análises de RPC mostraram valores de $a$ variando entre 0,0097-0,0149 e de $b$ entre 2,858-3,250. A análise da dieta mostrou que altas quantidades de insetos aquáticos ( $93,75 \%$ do total de itens) foram consumidas pela espécie. Além disso, não encontramos diferenças estatisticamente significativas quando comparamos a dieta entre os períodos seco e chuvoso. Nosso estudo contribui para o conhecimento da biologia populacional e ecologia alimentar de peixes trichomicterídeos em riachos brasileiros.

Palavras-chave: Bacia do Alto Paraná; Biologia populacional; Conteúdo estomacal; Peixe de riacho; Traço funcional.
} 


\section{Introduction}

The Trichomycteridae family — comprising siluriforms of freshwater ecosystems - holds a wide geographic distribution in South America; occurring, for example, from Andean to Brazilian waterbodies (e.g., Fernández \& Vari 2009; Reis et al. 2019; Katz \& Costa 2020). Most species are known to occur in surface waters (epigean), but some are found in hypogean environments (Rizzato et al. 2011; Castellanos-Morales 2010). In Brazil's freshwaters, most species occur in first to third order streams (e.g., Azevedo-Santos et al. 2020a). In the southeast of the country, many species of Cambeva and Trichomycterus have been reported (e.g., Casatti 2002; Lima et al. 2008; Barbosa \& Azevedo-Santos 2012; Katz et al. 2018; Cetra et al. 2020; Reis et al. 2020; Costa \& Katz 2021).

The genus Cambeva was recently proposed by Katz et al. (2018) based on Pygidium davisi Haseman, 1911. According to a recent compilation (Fricke et al. 2021), Cambeva holds over thirty described species. In just the Paranapanema River system (Upper Paraná River, Brazil), for instance, there were reported C. davisi (Haseman, 1911), C. diabola (Bockmann, Casatti $\&$ de Pinna, 2004), C. guareiensis Katz \& Costa, 2020, C. pascuali (Ochoa, Silva, Silva, Oliveira \& Datovo, 2017), and C. perkos (Datovo, Carvalho, \& Ferrer, 2012)(Katz \& Costa 2020). Cambeva guareiensis, in particular, occurs exclusively in small tributaries of sub-basins of the Paranapanema River system (Katz \& Costa 2020; Azevedo-Santos et al. 2020a; Lisboa et al. 2020).

Scientific data (e.g., biology) is scarce for most Cambeva species. For C. guareiensis, there are studies only recording its distribution in streams (e.g., Azevedo-Santos et al. 2020a) and describing a case of albinism (Azevedo-Santos et al. 2020b). Data on population biology and feeding ecology of the species need to be available in the scientific literature. This is justifiable especially by the eminent growth of functional studies that need basic information. For example, knowing the diet of species may be a useful trait for future investigations about anthropic impacts on fish assemblages.

Here we provide the length-weight relationship of $C$. guareiensis. In addition, we described and compared the diet of the species in different periods (dry and rainy).

\section{Material and Methods}

\section{Study area}

The Corrente stream, where the collections were performed, is a tributary of the Guareí River, which, in turn, flows to the Paranapanema River (upper Paraná River system; Azevedo-Santos et al. 2020a). The source of the Corrente stream is located at approximately 700 meters above sea level in the region of "Mineiros" ( 2324'9.44"S, 48²3'42.21”'W), in Angatuba municipality, São Paulo, Brazil. Fish were sampled above the waterfall of

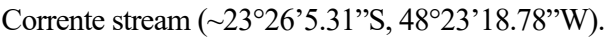

\section{Methods}

Sampling was done in September 2020 (dry season) and February 2021 (rainy season), and with the permission of the Brazilian Institute of Environment and Natural Resources (license number: SISBio 76135-1). Fish were caught with a hand net ( $1 \mathrm{~mm}$ mesh), in a stretch of $\sim 200$ meters of the Corrente stream. Sampling activity lasted $\sim 50$ minutes in both seasons. The collected specimens were euthanized with eugenol (exposed for more than 10 minutes - lethal dose) and fixed (with formalin $10 \%)$. Specimens were identified based on the original description provided by Katz \& Costa (2020). Vouchers (10 specimens that were transferred to alcohol $70 \%$ ) were deposited at the UFRJ (Universidade Federal do Rio de Janeiro, Rio de Janeiro, Brazil).

\subsection{Length-weight relationship}

The specimens were removed from formaldehyde, washed in water and then weighed $(0.1 \mathrm{~g})$ and measured (standard length; $0.1 \mathrm{~mm})$. Later they were transferred to alcohol (70\%) for diet analysis.

For the calculation of the length-weight relationship (LWR, hereafter), we considered together specimens collected in dry and rainy seasons. For the analyses, we used a linear regression " $\log W=$ $\log a+b \log L "$ (Froese 2006; p. 243). Through a plot (i.e., $\log -\log$ ) the outliers for Cambeva guareiensis were excluded (sensu Froese 2006).

\subsection{Diet}

For stomach content analysis, we made an incision in all specimens from the anus to the isthmus to remove the stomachs. The stomach contents were placed in Petri dish and examined using a stereomicroscope (Stemi 305).

The animal content present in the stomach of the trichomycterids was identified only to the level of Order or Family based on Costa et al. (2006) and Mugnai et al. (2010) because they were often in an advanced state of digestion (preventing the determination at lower levels). Sometimes contents could only be identified as terrestrial insects. Pieces of plant leaves and roots were also found (vegetal fragments). We used the abundance of the food items found in the stomach of the trichomycterids as the variable to quantify the diet of the species.

With the data obtained, we built a matrix with the abundance of each item consumed by each specimen. Individuals without content, or with an advanced digestion process, were not included in the analyses. From the constructed matrix, we compared the food of the individuals in both sampling seasons (dry vs. rainy), in order to verify possible seasonal variations. With data converted to $\log (x+1)$, we used a permutational multivariate analysis of variance (PERMANOVA), with 9999 permutations, and Bray-Curtis distance. For analysis, we used the software PRIMER 6.1.13 PERMANOVA+ 1.0.3 (Clarke \& Gorley 2006). Lastly, we also described the diet of the species using stomach contents during the studied period.

\section{Results}

\section{Length-weight relationship}

There were collected 58 individuals of Cambeva guareiensis (UFRJ 12717). The standard length of the specimens ranged from 24.062.5 millimeters and the weight from 0.18-3.70 grams. All sampled specimens were examined in the LWR (see Table 1).

\section{Diet}

Of the 58 specimens examined, 26 individuals sampled during dry season and 12 during rainy season had empty stomachs. The species ingested high amounts of aquatic insects (Figure 1), with predominance of Diptera of the families Chironomidae ( $56 \%$ of consumed items) and Simuliidae (14\%). They also consumed aquatic insects of Trichoptera, comprising $12 \%$ of items, and vegetal fragments (5.8\% of items). The PERMANOVA did not indicate a significant difference in species diet between dry and rainy seasons (Pseudo-F $=1.614, \mathrm{p}=0.159)$. 
LWR and diet of C. guareiensis

Table 1. Length-weight relationship of Cambeva guareiensis based on 58 individuals captured in Corrente stream, São Paulo, Brazil. The $a$ and $b$ refer to equation used (see Material and Methods section) ranging 95\% of confidence limits; and $\mathrm{R}^{2}$ refers to the correlation coefficient

\begin{tabular}{|c|c|c|}
\hline$a(95 \% \mathrm{CI})$ & $b(95 \% \mathrm{CI})$ & $\mathbf{R}^{2}$ \\
\hline $0.0123(0.0097-0.0149)$ & $3.054(2.858-3.250)$ & 0.946 \\
\hline
\end{tabular}

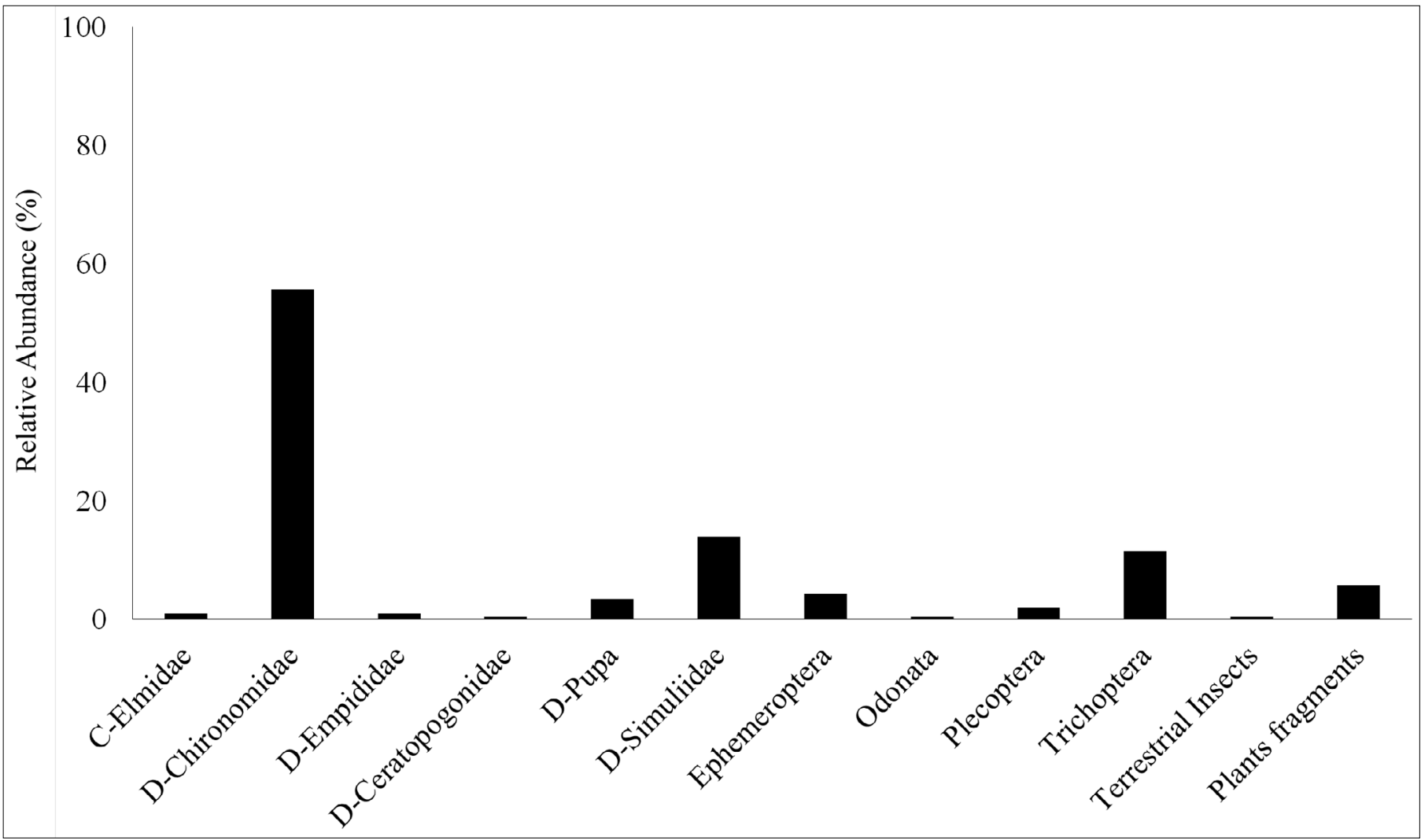

Figure 1. Relative abundance (\%) of insects and vegetal fragments consumed by the analyzed fish in the dry and rainy seasons. C-Coleoptera and D-Diptera.

\section{Discussion}

\section{Length-weight relationship}

The value of $b$ found for Cambeva guareiensis was 3.054 (2.858-3.250). Other species of the family Trichomycteridae, such as Trichomycterus candidus (Miranda Ribeiro, 1949), T. pirabitira Barbosa \& Azevedo-Santos, 2012, and T. piratymbara Katz, Barbosa \& Costa, 2013 (identification corrected herein to T. sainthilairei Katz \& Costa, 2021, UFRJ 12719), had similar patterns (Azevedo-Santos et al. 2018). In fact, many stream fish species are expected to have $b$ values in a similar range as that found for $C$. guareiensis and other trichomycterids (Froese 2006).

\section{Diet}

Insects were the main food item found in the stomach contents of the individual examined, especially aquatic insects. Other studies (e.g., Casatti 2002; Chará et al. 2006; Scott et al. 2007; Manoni et al. 2009; Rondineli et al. 2009) showed that other species of the same family or genus that $C$. guareiensis also feed on this group. The low prevalence of vegetal items, when compared with insects, and the morphology of the digestive system of $C$. guareiensis, suggests that leaves and roots were accidentally ingested during prey capture or that plants are not an important item in the diet of this species. However, only with the analysis of the diet-without observations in situ of the feeding behavior of the C. guareiensis (e.g., Casatti 2002)-, is impossible to confirm the first possibility suggested.

We found no statistically significative differences in the diet of C. guareiensis between different seasons (i.e., dry vs. rainy). Similar results were found by Manoel \& Uieda (2019) for other species of the genus Cambeva in one impacted stream. A possible explanation is that Corrente stream has a similar characteristic such as those reported by these authors. Another explanation is that the availability of insects in the aquatic ecosystem may modulate the presence of this item in the diet of trichomycterids (sensu Scott et al. 2007). Therefore, the absence of seasonal changes in the diet of $C$. guareiensis may be related to low or no seasonal variation in the availability of aquatic insects in the stream, which was the predominant group among the food items. Both lines of investigation deserve attention in futures studies in Guareí River basin.

Here we contribute to the knowledge about the biology (LWR) and feeding ecology of C. guareiensis. These baseline data are extremely important, for example, for future studies on functional diversity. Trichomycteridae is a large and varied family of fishes (see de Pinna \& Wosiacki 2003 with numerous species with little or no biological and ecological data. Therefore, studies in both fields should be encouraged for other species of the family. 


\section{Acknowledgments}

We are grateful to Raoul Henry (UNESP), for help with the fieldwork, Axel Katz (UFRJ), for the help with the vouchers, and Faculdade EDUVALE de Avaré, for the logistical support. We would like to thank Donald C. Taphorn (Royal Ontario Museum), the two anonymous reviewers, and the Associate Editor, for their corrections and suggestions that greatly improved the quality of this article.

\section{Author Contributions}

Felipe H. N. P. Ribeiro: Collected the trichomycterids, led the writing, analyzed data, and collaborated with the writing.

Maria E. P. Bonan: Collected the trichomycterids, led the writing, analyzed data, and collaborated with the writing.

José Lucas Dias da Silva: Collected the trichomycterids and collaborated with the writing.

Valter M. Azevedo-Santos: Collected the trichomycterids, identified them, analyzed data, and collaborated with the writing.

Pedro S. Manoel: Analyzed the stomachs, analyzed data, and collaborated with the writing.

Eduardo M. Brambilla: Analyzed data and collaborated with the writing.

Carolina V. Silva: Idealized the work, collected the trichomycterids, analyzed the stomachs, analyzed data, and collaborated with the writing.

\section{Conflicts of interest}

The authors declare that they have no conflict of interest related to the publication of this manuscript.

\section{References}

AZEVEDO-SANTOS, V.M., COELHO, P.N., BRAMBILLA, E.M., LIMA, F.P., NOBILE, A.B., \& BRITTON, J.R. 2018. Length-weight relationships of four fish species from the upper Paraná River basin, Southeastern Brazil. J. Appl. Ichthyol. 34: 237-239. https://doi.org/10.1111/jai.13542

AZEVEDO-SANTOS, V.M., PELICICE, F.M., HENRY, R. 2020a. Knowing biodiversity: Fishes from the Guareí River basin, a tributary of the Jurumirim reservoir, Paranapanema River, Brazil. Biota Neotrop. 20(3): e20201031. https://doi.org/10.1590/1676-0611-BN-2020-1031

AZEVEDO-SANTOS, V.M., PELICICE, F.M., SAZIMA, I., HENRY, R. 2020b. A case of complete albinism in the catfish Cambeva guareiensis (Siluriformes: Trichomycteridae). Biota Neotrop. 20(4): e20201066. https:// doi.org/10.1590/1676-0611-BN-2020-1066

BARBOSA, M.A., AZEVEDO-SANTOS, V.M. 2012. A new species of the catfish genus Trichomycterus (Teleostei: Siluriformes: Trichomycteridae) from the rio Paraná basin, southeastern Brazil. Vertebr. Zool. 62 (3): 357-362.

CASATTI, L. 2002. Alimentação dos peixes em um riacho do Parque Estadual Morro do Diabo, bacia do Alto Rio Paraná, sudeste do Brasil. Biota Neotrop. 2(2): http://www.biotaneotropica.org.br/v2n2/pt/ abstract?article+BN02502022002

CASTELLANOS-MORALES, C.A. 2010. Trichomycterus sketi: a new species of subterranean catfish (Siluriformes: Trichomycteridae) from the Andean Cordillera of Colombia. Biota Colomb. 11: 33-41

CETRA, M., MATTOX, G., ROMERO, P.B., ESCOBAR, S.H., GUIMARÃES, E.A., TURIN, R.A.F. 2020. Ichthyofauna from "serranias costeiras" of the Ribeira de Iguape River basin, Southeast Brazil. Biota Neotrop. 20(4): e20200094. https://doi.org/10.1590/1676-0611-BN-2020-0994

CHARÁ, J.D., BAIRD, D.J., TELFER, T.C., RUBIO, E.A. 2006. Feeding ecology and habitat preferences of the catfish genus Trichomycterus in low-order streams of the Colombian Andes. J. Fish Biol. 68(4): 1026-1040.
CLARKE, K.R., GORLEY, R. . 2006. Primer v6: User manual/tutorial. Plymouth: Plymouth Marine Laboratory.

COSTA, C., IDE, S., SIMONKA, C.E. 2006. Insetos imaturos: metamorfose e identificação. Ribeirão Preto: Holos Editora.

COSTA, W.J.E.M., KATZ, A.M. 2021. Integrative taxonomy supports high species diversity of south-eastern Brazilian mountain catfishes of the T. reinhardti group (Siluriformes: Trichomycteridae). System. Biodivers. https://doi.org/10.1080/14772000.2021.1900947

de PINNA, M.C.C.; WOSIACKI, W. 2003. Trichomycteridae (Pencil or parasitic catfishes). In: REIS, R. E., KULLANDER, S. O., FERRARIS JR, C. J. (Ed.). Check List of the Freshwater Fishes of South and Central America. Porto Alegre: EDIPUCRS, 2003. p. 270-290.

FERNÁNDEZ, L., VARI, R.P. 2009. New species of Trichomycterus from the Andean Cordillera of Argentina (Siluriformes: Trichomycteridae). Copeia (1): 195-202.

FRICKE, R., ESCHMEYER, W.N., VAN DER LAAN, R. (EDS) 2021. ESCHMEYER'S CATALOG OF FISHES: GENERA, SPECIES, REFERENCES. (http://researcharchive.calacademy.org/research/ichthyology/ catalog/fishcatmain.asp). Electronic version accessed 24/06/2021.

FROESE, R. 2006. Cube law, condition factor and weight-length relationships: history, meta-analysis and recommendations. J. Appl. Ichthyol. 22: 241-253.

KATZ, A.M., BARBOSA, M.A., MATTOS, J.L.O., COSTA, W.J.E.M. 2018. Multigene analysis of the catfish genus Trichomycterus and description of a new South American trichomycterine genus (Siluriformes, Trichomycteridae). Zoosyst. Evol. 94(2), 557-566.

KATZ, A.M., COSTA, W.J.E.M. 2020. A new species of the catfish genus Cambeva from the Paranapanema river drainage, southeastern Brazil (Siluriformes: Trichomycteridae). Trop. Zool. 33(1): 2-13. https://doi.org/10.4081/tz.2020.63

LIMA, S.M.Q., LAZZAROTTO, H., COSTA. W.J.E.M. 2008. A new species of Trichomycterus (Siluriformes: Trichomycteridae) from lagoa Feia drainage, southeastern Brazil. Neotrop. Ichthyol. 6(3): 315-322.

LISBOA, I.I., ALMEIDA, A.S., COSTA, E. V.I., MARTINS, G.L., FERREIRA, L. M. S., BARROS, T.R., NUNES, S.A. S., OLIVEIRA, M.I. M., AZEVEDOSANTOS, V. M. 2020. Os peixes do Ribeirão Bom Retiro. In: HENRY, R., LISBOA, I.I., CRUZ, C.A. da. (Org.). Águas da Esperança. Uma pesquisa participação: Parceria entre a educação básica e a universidade. 1ed. p. 107-114.

MANOEL, P.S., UIEDA, V.S. 2019. Long-term effects of a rural landscape on the structure and trophic organization of a fish assemblage. Acta Limnol. Bras. 31.

MANONI, R., GARELIS, P., TRIPOLE, E., VALLANIA, E. 2009. Diet and feeding preferences of Trichomycterus corduvensis Weyenbergh, 1877 (Siluriformes, Trichomycteridae) in two rivers of the Quinto River basin (San Luis, Argentina). Biological Limnology 21: 161-167.

MUGNAI, R., NESSIMIAN, J.L., BAPTISTA, D.F. 2010. Manual de identificação de macroinvertebrados aquáticos do Estado do Rio de Janeiro. 1. ed. Rio de Janeiro: Technical Books.

REIS, R.B., FROTA, A., FABRIN, T.M.C. DA GRAÇA, W.J. 2019. A new species of Cambeva (Siluriformes, Trichomycteridae) from the Rio Ivaí basin, Upper Rio Paraná basin, Paraná State, Brazil. J. Fish Biol. 96: 350-363.

REIS, V.J.C., SANTOS, S.A., BRITTO, M.R., VOLPI, T.A., DE PINNA, M.C.C. 2020. Iterative taxonomy reveals a new species of Trichomycterus Valenciennes 1832 (Siluriformes, Trichomycteridae) widespread in Rio Doce basin: a pseudocryptic of T. immaculatus. J. Fish Biol. 97: 1607-1623. https://doi.org/10.1111/jfb.14490

RIZZATO, P.P., COSTA-JR., E.P.D., TRAJANO, E., BICHUETTE, M.E. 2011. Trichomycterus dali, a new highly troglomorphic catfish (Siluriformes: Trichomycteridae) from Serra da Bodoquena, Mato Grosso do Sul state, Central Brazil. Neotrop. Ichthyol. 9(3): 477-491.

RONDINELI, G.R., CARMASSI, A. L., BRAGA, F.M.D.S. 2009. Population biology of Trichomycterus sp. (Siluriformes, Trichomycteridae) in Passa Cinco stream, Corumbataí river sub-basin, São Paulo state, southeastern Brazil. Braz. J. Biol. 69(3): 925-934.

SCOTT, S., PARDO, R., VILA, I. 2007. Trophic niche overlap between two Chilean endemic species of Trichomycterus (Teleostei: Siluriformes). Rev. Chil. de Hist. Nat. 80(4): 431-437.

Received: 05/05/2021

Revised: 29/06/2021

Accepted: 07/07/2021

Published online: 03/09/2021 